Published in final edited form as:

Chem Biodivers. 2013 September ; 10(9): . doi:10.1002/cbdv.201300211.

\title{
C13211. Ethnochemistry and Human Rights
}

\author{
Inna Abramova and Alexander Greer \\ Department of Chemistry, The City University of New York, Brooklyn College, 2900 Bedford \\ Avenue, Brooklyn, New York 11210, United States
}

\section{Keywords}

ethnochemistry; human rights; indigenous communities; self-determination; biopiracy

\begin{abstract}
Any effort where drugs, supplements, and other high value products have been developed as an outgrowth of ethnochemical knowledge should acknowledge the community from which the knowledge originated. This community should receive some form of reciprocal gain. Such reciprocity could be in the form of technology transfer and training, and in the event that a compound is successfully commercialized, royalty payments. This is a crucial topic that needs to be discussed among chemists. A key point is that recently the United Nations General Assembly has adopted the Declaration on the Rights of Indigenous Peoples [1], which includes the right to self-determination. We encourage chemists to recognize and defend this right.
\end{abstract}

The relationship between science and the human rights of indigenous groups has often been a difficult one [2], with the history of drug discovery being particularly problematic. Ethnochemical development can be viewed as a 2-step process: One is the use of indigenous knowledge as a starting point for chemicals as leads. The second is advancing the chemical leads, by further testing and patenting of them. As chemists, we remember the second, but usually fail to recognize the importance of the first.

\section{Roles that indigenous people have played in making a natural products discovery available for modern chemistry}

Modern chemistry tactics that use indigenous knowledge are common. For example, traditional knowledge is often a starting point in drug discovery [3], including: aspirin and codeine (pain treatment); quinine (treatment of malaria); pilocarpine (treatment of glaucoma), and Sangre de Grado (treatment of diarrhea). The plant Artemisia annua has been used for over two thousand years in Chinese traditional medicine for its antimalarial properties; the active agent is artemisin and is used today on large scales [4]. Several thousands of natural products and mixtures are currently used in medicine with origins from European, Asiatic, and American Indian healers [5] [6]. Healers do not isolate compounds. Instead, they make preparations that concentrate groups of compounds. The patenting process for ethnomedicinal processes in the pharmaceutical industry can be abusive, and can even represent outright biopiracy [1] [2] [7] [8] [9].

\section{Encouraging Discussion and Debate}

Discussion and debate of biopiracy within the scope of chemistry is needed. 
Biopiracy is defined as:

- The wrongful appropriation of indigenous knowledge of chemicals for commercial or other gain by non-indigenous people

- The patenting of specific compounds from traditional medicines

- The lack of contractual relations for "reciprocal exchange"

Doctrinal and theoretical questions include:

- What methods should be used to assess the level of new knowledge generated by patents of compounds that used indigenous knowledge?

- How does one quantitate theft of indigenous knowledge in patents of compound leads?

- Is it biopiracy if

(a) Indigenous knowledge depends on a group of natural products, where some are related and some are not?

(b) The plant was used in its whole form, or if it were used for a different need such as therapeutic need, with a different mode of action?

(c) Non-indigenous scientists' document and publish on natural products based on traditional medicines?

It is important that the debate incorporate different perspectives on the issues including:

- Human rights

- Science

- Law

- $\quad$ Public policy

- $\quad$ Ethics

The context for discussion of the ethics of knowledge transfer between indigenous peoples and scientists is often poorly-defined [10] [11] [12], which leads to oversimplified discussion. This is counterproductive. Justice would be served by the acknowledgement of indigenous peoples' right to control their own knowledge [13], and the obligation of outsiders to respect them by arrangements such as contracts for reciprocal exchange [14] [15].

\section{Right to Self-Determination}

It is key that the United Nations General Assembly has adopted the Declaration on the Rights of Indigenous Peoples (UN DRIP) [1], which includes the right to self-determination. The UN DRIP describes the moral duties of nation-states and its citizens, what they owe indigenous peoples, and how indigenous peoples should be respected.

UN DRIP is a prescriptive document and it is good progress, it describes what the human rights of indigenous peoples are. It does not convey legal duties and it is not mandatory. However, importantly, article 31 of the UN DRIP describes the right of indigenous peoples to control and protect their own traditional knowledge and for nation-states to guarantee these rights. Thus, it is important that the UN DRIP can be enforced by treaty or by domestic legislation. 
The UN Convention on Biological Diversity (article 8) is a treaty describing equitable benefits-sharing with indigenous groups with aims to promote the well-being of society, but is only binding for countries that have signed it. A leading expert on tribal sovereignty and cultural rights is Rebecca Tsosie [16]. She raises awareness that this document can provide the basis of legal duties in those countries that have signed onto the Convention.

\section{Non-zero sum}

Many drug leads and other chemicals remain to be discovered in marine and terrestrial natural product sources. Traditional knowledge is usually focused on land plants, where examples from marine compounds are extremely rare. Traditional knowledge-guided medical uses of natural products can provide the identification of drug leads and lead to further structure-activity studies [17].

Many indigenous communities believe that their knowledge has been used effectively for generations and it is best conserved not by sharing it with outsiders [16]. This point is, however, not without some disagreement [5] [18] [19] [20]. To be sure, the problems of protecting intellectual property [21] coexist with other pressing issues, including the steady loss of plant biodiversity and genetic resources [22] [23]. The topic is complex and varied, and is inherently interdisciplinary as traditional knowledge is not easily placed into distinct categories such as supramolecular chemistry or photochemistry.

Several benefit-sharing policies have been adopted, such as the International Cooperative Biodiversity Groups Program [24] [25]. Joshua Rosenthal of the National Institutes of Health's Fogarty International Center is exceptional among scientists who lead the cause [26]. The chemical community owes Dr. Rosenthal and his colleagues gratitude for developing a framework by which technology can be shared between indigenous groups and Pharma, including the work with National Cancer Institute programs to establish Cooperative Research and Development Agreements. For 25 years, Paul Alan Cox of the Institute for EthnoMedicine has been committed to the cause of empowering indigenous groups in the search for new drugs [27]. In 1997, Thomas Eisner helped to broker an agreement between Merck and Costa Rica [28]. In 2003, the American Association for the Advancement of Science (AAAS) produced a handbook [29], and in 2012 hosted a meeting on indigenous peoples' rights, human rights, science and technology [30], but more progress is still greatly needed.

While the exceedingly low success rate of discovery of blockbuster-type drugs is described in chemistry journals, indigenous contributions to chemistry and drug discovery are rarely discussed. Giving due credit to Samoan healers for the drug candidate prostratin was described in Science magazine [27]. But to be certain, the topic of biopiracy is rarely included in chemistry education, and most chemists do not talk about it.

\section{Future Prospects}

How can the problem of biopiracy be overcome given the different legal systems in the world? Chemists involved in drug discovery and the development of valuable chemicals should recognize and defend the UN DRIP aggressively. Failing to pursue a solution would represent a rejection of indigenous knowledge, acknowledging that links between indigenous peoples and consumer nations are wrapped in a complex web. If a benefitsharing solution continues to be seen as undesirable or unattainable, the limited success of the status quo will remain unchanged.

We know that the human rights of indigenous peoples can be violated even when scientists may be in compliance with domestic law, such as intellectual property rights laws. It is 
necessary that chemists understand what the human rights of all indigenous peoples are, which are different from their "legal rights" under a particular country's domestic law. Our bottom line is that we urge chemists to discuss and seek enlightened rejection of biopiracy, that pharmaceutical companies become more educated in the law, and heed to indigenous self-determination as a moral obligation.

\section{Acknowledgments}

We are grateful for the comments and suggestions of Mark Kobrak, Joshua P. Rosenthal, Rebecca Tsosie, and to Leda Lee for the graphic arts work, and for the support from the National Institutes of Health (Grant No. SC1GM093830)

\section{REFERENCES}

1. UN General Assembly. Washington 12; UN: 2007. United Nations Declaration on the Rights of Indigenous Peoples. A/RES/61/295

2. Tsosie R. Wash. L. Rev. 2012; 87:1133.

3. Cox PA. Ciba Found. Symp. 1994; 185:25. [PubMed: 7736859]

4. Feth MP, Rossen K, Burgard A. Org. Process Res. Dev. 2013; 17:282.

5. Farnsworth NR, Morris RW. Am. J. Pharm. Sci. Support. Public Health. 1976; 148:46. [PubMed: 984178]

6. Cragg, G.; Asebey, E. Valuing Local Knowledge: Indigenous People and Intellectual Property Rights. In: Brush, SB.; Stabinsky, D., editors. Island Press; p. 1996

7. Stenton G. Eur. Intellect. Property Rev. 2004; 26:17.

8. Elisabetsky E. Cult. Surv. Q. 1991; 15:9.

9. Harry D. Biopiracy and Globalization: Indigenous Peoples Face a New Wave of Colonialism. Indigenous People Council on Biocolonialism. :2001.

10. Huft MJ. Nw. UL Rev. 1994; 89:1678.

11. Macilwain C. Nature. 1998; 392:535. [PubMed: 9560137]

12. Puri M, Masum H, Heys J, Singer PA. BMC Int. Health Hum. Rights. 2010; 10(Suppl 1):S9. [PubMed: 21144080]

13. M. Elvin-Lewis. Afr. J. Tradit. Complement. Altern. Med. 2007; 4:443. [PubMed: 20161913]

14. Graber, CB.; Kuprecht, K.; Lai, JC. Edward Elgar Press; London: International Trade in Indigenous Cultural Heritage; p. 2012

15. Shingu GK. Ethnobotany Res. Appl. 2005; 3:17.

16. Tsosie, R. International Trade in Indigenous Cultural Heritage. In: Graber, CB.; Kuprecht, K.; Lai, JC., editors. Edward Elgar Press; London; 2012. p. 240

17. Newman DJ, Cragg GM. Buss AD, Butler MS. Natural Product Chemistry for Drug Discovery. 2010:3.

18. Cox PA. Science. 2000; 287:44. [PubMed: 10644221]

19. Mathez-Stiefel SL, Brandt R, Lachmuth S, Rist S. Human Ecol. 2012; 40:909.

20. Vandebroek I, Balick MJ. PLoS ONE. 2012; 7:e37643. [PubMed: 22662184]

21. Kim HS. J. Ethnopharmacol. 2005; 100:37. [PubMed: 16039812]

22. Kingston DG. J. Nat. Prod. 2010; 74:496. [PubMed: 21138324]

23. Cordell GA, Colvard MD. J. Ethnopharmacol. 2005; 100:5. [PubMed: 16009517]

24. Aponte JC, Vaisberg AJ, Rojas R, Sauvain M, Lewis WH, Lamas G, Sarasara C, Gilman RH, Hammond GB. J. Nat. Prod. 2009; 72:524. [PubMed: 19199646]

25. Soejarto DD, Fong HHS, Tan GT, Zhang HJ, Ma CY, Franzblau SG, Gyllenhaal C, Riley MC, Kadushin MR, Pezzuto JM, Xuan LT, Hiep NT, Hung NV, Vu BM, Loc PK, Dac LX, Binh LT, Chien NQ, Hai NV, Bich TQ, Cuong NM, Southavong B, Sydara K, Bouamanivong S, Ly HM, Thuy TV, Rose WC, Dietzman GR. J. Ethnopharmacol. 2005; 100:15. [PubMed: 15993554] 
26. Cragg GM, Katz F, Newman DJ, Rosenthal J. Nat. Prod. Rep. 2012; 29:1407. [PubMed: 23037777]

27. Cox PA, Johnson HE, Tavana G. Science. , 320. 2008:1589. [PubMed: 18566269]

28. Zebich-Knos M. J. Environ. Development. 1997; 6:180.

29. Hansen, SA.; VanFleet, JW. American Association for the Advancement of Science (AAAS), Science and Human Rights Program; Washington, DC: Jul. Traditional Knowledge and Intellectual Property: A Handbook on Issues and Options for Traditional Knowledge Holders in Protecting Their Intellectual Property and Maintaining Biological Diversity; p. 2003

30. AAAS Science and Human Rights Coalition Meeting Report; Jan. 2012 p. 7-9.srhrl.aaas.org/ coalition/Meetings/2012/January/Report.pdf 